\title{
Review of Present UK Marine Energy Policy and Developments
}

\author{
M.R. Willis ${ }^{1}$, A. Cook ${ }^{1}$, A.J. Williams ${ }^{1}$, I. Masters ${ }^{1}$, T.N. Croft ${ }^{1}$ \\ ${ }^{1}$ Marine Energy Research Group \\ School of Engineering \\ Swansea University, Singleton Park, Swansea, UK, SA2 8PP \\ Phone/Fax number:+0044 792 295541, e-mail: $\underline{\text { m.r.willis@swansea.ac.uk, }}$
}

\begin{abstract}
.
Marine renewable energy can meet the challenges of climate change and energy security. It is highly predictable making it invaluable to an energy portfolio. The UK, being surrounded by oceans, is well positioned to exploit the marine renewable energy resource of approximately $89 \mathrm{TWh} /$ year. Between 1-2.5 GW could be deployed by 2020 , providing $3 \%$ of UK electricity.
\end{abstract}

This paper looks at the UK Government policies to encourage growth in marine renewables, focusing specifically on Wales and the Welsh Assembly Government's ambitous objectives. The Welsh Assembly Government Renewable Energy Route Map for Wales includes an ambition to produce more electricity from renewables than Welsh consumers demand within 20 years.

A new marine renewable energy industry has advantages beyond carbon reduction targets. Domestically sourced energy will alleviate energy security concerns, give employment and create export opportunities.

Currently, the UK is considered to be the furthest along the road to commercial marine renewable devices, however, the rest of the world are increasingly closing the lead. To prevent Britain being overtaken, as occurred in the development of the wind industry, investor confidence must be increased through government policy intervention, backed up with governmental action.

\section{Key words}

Marine Energy, policy, UK, market support, grant schemes.

\section{Introduction}

Marine renewable energy has the potential to help combat the increasing challenges of climate change and energy security. Unlike other forms of renewable energy it is highly predictable making it an invaluable asset to a renewable energy portfolio. The UK, being surrounded by oceans, is well positioned to exploit the abundant marine renewable energy resource.

The technology necessary to convert the ocean's energy into a usable power commodity already exists. However, the industry is currently restrained by its infancy and the venture risks associated long cash-burn periods with an uncertain return using unproven technology.

Currently the UK is considered to be the furthest along the road to the commercialisation of marine renewable energy devices, however the rest of the world are increasingly closing the lead. To prevent Britain being overtaken, as occurred in the development of the wind industry, investor confidence must be increased. One mechanism to achieve this is through government policy intervention, backed up with governmental action.

This paper looks at the UK Government's policies and initiatives that are designed to encourage the growth of the nascent marine renewable energy, focusing specifically on the Wales and the Welsh Assembly Government's objective to take place Wales at the forefront of the development of global marine renewable energy sector.

\section{Potential}

The UK's predicted potential marine energy from wave, tidal range and tidal stream sources is sourced from the DTI's Energy Technology Support Unit ${ }^{1}$, AEA Energy and Environment ${ }^{2}$ and Black and Veatch ${ }^{3}$ respectively. The optimal amount that can be generated is approximately $86 \mathrm{TWh} /$ year, the equivalent to $26.6 \%$ of the UK's energy demand in $2006^{4}$. (Based on 2006 energy consumption in the UK excluding Northern Ireland). The UK marine renewable resource is summarised in Table I. 
Table I - The UK's marine renewable energy resource

\begin{tabular}{|c|c|c|c|c|}
\hline & & $\begin{array}{l}\text { Estimated } \\
\text { Generation } \\
\text { (TWh/yr) }\end{array}$ & $\begin{array}{c}\text { Total } \\
\text { generation per } \\
\text { source }(\mathrm{TWh} / \mathrm{yr})\end{array}$ & $\begin{array}{l}\text { Contribution to UK } \\
\text { Electricity Demand - } \\
\text { Based on } 2006(\%)\end{array}$ \\
\hline \multirow[t]{3}{*}{ Wave } & & & 52.100 & 16.059 \\
\hline & Nearshore & 2.100 & & 0.647 \\
\hline & Offshore & 50.000 & & 15.412 \\
\hline \multirow[t]{8}{*}{ Tidal Range } & & & 18.810 & 5.798 \\
\hline & Severn Estuary ${ }^{3}$ & & & \\
\hline & Shoots Barrage OR & 2.700 & & 0.832 \\
\hline & Cardiff Western Barrage & 17.000 & & 5.240 \\
\hline & Mersey Barrage & 1.450 & & 0.447 \\
\hline & Loughor Barrage & 0.015 & & 0.005 \\
\hline & Duddon Barrage & 0.212 & & 0.065 \\
\hline & Wyre Barrage & 0.133 & & 0.041 \\
\hline \multirow[t]{3}{*}{ Tidal Stream } & & & 15.400 & 4.747 \\
\hline & Top 10 sites & 11.200 & & \\
\hline & Total UK & 15.400 & & \\
\hline Total & & & 86.310 & 26.603 \\
\hline
\end{tabular}

The Carbon Trust (CT) estimate that marine renewable energy could provide 3\% of the UK's electricity by 2020 . That is between $1 \mathrm{GW}$ and $2.5 \mathrm{GW}$ being deployed ${ }^{5}$.

\section{International Policies}

The European Union (referring to the EU's first 15 member states) as a signatory of the Kyoto Protocol is obliged to reduce GHG emissions by $8 \%$ compared to 1990 levels by 2012. To meet this obligation the EU devised the European Union Emission Trading Scheme (EU ETS). Although indirect, the ETS does imply a concentration of resources into renewable energy including marine energy.

In the spring summit of 2007, the EU heads of State agreed that the EU would cut GHG emissions by $20 \%$ by 2020 (compared to 2005), including a binding target of $20 \%$ renewable energy. (The emission reductions could increase to a $30 \%$ target if other developed countries match this commitment.) For the UK this implies a $16 \%$ reduction in emissions with a $15 \%$ target for renewable energy $^{6}$. This is all part of an emerging Energy Policy for Europe $^{7}$.This has direct implications for the UK, the binding renewable energy target will require the exploitation of all renewable energy sources. Marine energy may only play a small part in this 2020 target but the technology will be needed increasingly to meet targets thereafter.

Beyond the 2020 target, the EU aims to 'accelerate the development and deployment of cost-effective low carbon technologies' with a vision of complete decarbonisation of the energy sector by 2050. This includes ensuring emerging technologies come on-stream as early as possible . $^{8}$

\section{UK Policies}

The UK has put energy and climate change policy firmly onto the national agenda. This is reflected in a 2008 departmental reorganisation resulting in the creation of the Department of Energy and Climate Change (DECC). The new department has increased the long-term 2050 greenhouse gas emissions reductions from $60 \%$ to $80 \%$ in the Climate Change Act (2008).
The consultation on a UK Renewable Energy Strategy, proposes $14 \%$ renewable energy from heat, $10 \%$ from transport, and $32 \%$ in electricity ${ }^{9}$. For the UK to meet the renewable electricity target by 2020 , the Renewable Obligation (RO) is envisaged as the primary driver. This has encouraged renewable electricity generation since succeeding the Non-Fossil Fuels Levy in 2002, with markedly improved results. Thus far the RO has done little to incentivise marine renewable energy specifically, as investors have adopted more proven and developed technologies namely on and offshore windfarms. To address this and prevent a gap between established and emerging technologies DBERR have reformulated the RO so that technologies are attributed a varying level of Renewable Obligation Certificates (ROCs) with marine technologies receiving at least 2 per MWh, see Table II.

Table III. Renewable Obligation proposed bands

\begin{tabular}{|c|c|c|}
\hline & Technologies Applicable & ROCs per MWh \\
\hline Established & $\begin{array}{l}\text { Sewage gas; landfill gas; co-firing of } \\
\text { non-energy crop biomass }\end{array}$ & 0.25 \\
\hline Reference & $\begin{array}{l}\text { Onshore wind; hydro-electric; co-firing } \\
\text { of energy crops; energy from waste with } \\
\text { combined heat and power }\end{array}$ & 1 \\
\hline Post-Demonstration & $\begin{array}{l}\text { Offshore wind; dedicated regular } \\
\text { biomass }\end{array}$ & 1.5 \\
\hline $\begin{array}{l}\text { Emerging } \\
\text { Technologies }\end{array}$ & $\begin{array}{l}\text { Wave; tidal stream; anaerobic digestion; } \\
\text { gasification; pyrolysis; dedicated } \\
\text { biomass burning crops, dedicated } \\
\text { regular biomass with combined heat } \\
\text { and power; photovoltaics; geothermal }\end{array}$ & 2 \\
\hline
\end{tabular}

Included in the consultation document wave and tidal energies are expected to account for less than $1 \%$ and $3 \%$ respectively of the total $15 \%$ target. This equates to less than 2.65 TWh annually of wave energy and 7.95 TWh annually of tidal energy.

The UK Government along with the devolved administrations have made policies for renewable energy, summarised in Table III but the challenge remains to realise these policy targets.

Table III. UK Marine renewable energy targets

\begin{tabular}{l|ccccc}
\cline { 2 - 6 } \multicolumn{1}{l|}{} & $\begin{array}{c}\text { Renewable } \\
\text { sourced } \\
\text { electricity (\%) }\end{array}$ & $\begin{array}{c}\text { Renewable } \\
\text { sourced electricity } \\
\text { (TWh based on } \\
\text { 2006 demand) }\end{array}$ & $\begin{array}{c}\text { Marine sourced } \\
\text { electricity (\% of } \\
\text { total electricity) }\end{array}$ & $\begin{array}{c}\text { Marine sourced } \\
\text { electricity (TWh } \\
\text { based on 2006 } \\
\text { demand) }\end{array}$ & $\begin{array}{c}\text { Target } \\
\text { year }\end{array}$ \\
\hline $\begin{array}{l}\text { UK } \\
\text { Scotland }\end{array}$ & 52 & 103.8 & $<3$ & $<7.95$ & 2020 \\
Wales & 100 & 14.7 & 10 & 2.9 & 2020 \\
\hline $\begin{array}{l}\text { a assuming the contribution of half the Cardiff-Western Barrage } \\
\text { b assuming no contribution from a Cardiff-Western Barrage }\end{array}$ & 82a or 30b & 14 a or 5b & 2025 \\
\hline
\end{tabular}

The UK support marine energy as an innovation technology, applicable for the longer-term as implied in the UK Renewable Energy Strategy. The key sources of research funding coming from academic Research Councils, the Technology Strategy Board, the Energy Technologies Institute (ETI), Carbon Trust (CT) and the UK Environmental Transformation Fund. 
The ETI is a $£ 1 b n, 10$ year 50:50 public private partnership to improve energy technologies, including marine energy. One of the first projects was a $1 \mathrm{MW}$ tidal technology programme for analytical and environmental assessment of tidal turbines as well as the creation of certification guidelines ${ }^{10}$.

The CT Applied Research Programme provides grants if they are likely to reduce UK carbon emissions. Out of $£ 17 \mathrm{~m}, £ 3 \mathrm{~m}$ has gone to 15 marine renewables projects.

The CT Marine Energy Accelerator (MEA) follows on from the Marine Energy Challenge (MEC), and focuses on cost reductions. The $£ 42 \mathrm{~m}$ Marine Renewable Deployment Fund (MRDF) was established August 2004 by the then DTI to 'plug' a 'funding-gap' for precommercial development. An additional $£ 8 m$ supports associated infrastructural or environmental projects.

The MRDF's Demonstration Scheme provides a $25 \%$ capital grant of eligible costs with a $£ 100$ per MWh produced, up to a maximum of $£ 9 \mathrm{~m}$ per project. Since 2006 the MRDF has not yet received an application that has met the prerequisite of having demonstrated a working prototype of three months continuous generation. The Renewables Advisory Board has recommended that the MRDF become more flexible to support the self-set targets of the industry ${ }^{11}$.

The MRDF has helped fund a 'Wave Hub' for testing arrays of wave energy converters off the coast of Cornwall $^{12}$. This will provide up to $20 \mathrm{MW}$ of grid connection in an $8 \mathrm{~km}^{2}$ area of sea ${ }^{11}$. The Hub is expected to cost $£ 28 \mathrm{~m}$ with $£ 4.5 \mathrm{~m}$ being derived through the $\mathrm{MRDF}^{11}$. The project was intended to be completed for summer 2009, however, a 'disappointing response from the market' has led to installation being pushed back to spring $2010^{13}$. As well as the European Marine Energy Centre in Orkney and the Wave Hub, marine devices are supported at an earlier stage of development at the New and Renewable Energy Centre (NaREC). More than ten wave device developers and two tidal devices developers have used the large-scale wave tank in the former dry dock and tidal current testing facility in the Tees Barrage $^{11}$.

\section{Political Support}

One of the greatest barriers to marine energy deployment is the consenting process. In order to create a more streamlined process for consenting the following have been or are being undertaken.

\section{The Planning and Energy Act 2008}

This Act establishes an Infrastructure Planning Commission (IPC) designed to ensure coherent planning of resources and activities, allowing all aspects of a project, including power generation, to be considered holistically. This should also make it easier for developers who would only need to consult one body (regarding planning). The Commission's remit for energy would be for stations $50 \mathrm{MW}$ and above onshore and 100 MW and above for offshore ${ }^{14}$.

\section{The Marine and Coastal Access Bill}

This Bill, published by the Department for Environment Food and Rural Affairs (DEFRA) in April 2008, was introduced to the House of Lords by Lord Hunt representing DECC in December 2008. The Bill will be subject to scrutiny as it transits through the House of Lords, the House of Commons and then back to the House of Lords before it receives Royal Assent.

The main themes of the Bill that will affect the development of a marine energy industry are:

- The development of a Marine Management Organisation (MMO),

- Marine planning system for marine resources,

- Nature conservation,

- Improved administration and licensing.

This Bill is especially significant for a marine energy industry as it will reformat the incremental production of legislation responsible for many of the delays thus far. All maritime developments will be considered objectively amongst other well-established industries, which could otherwise be almost impossible to infiltrate.

The creation of a single authoritative body, the MMO, will simplify the consents process, offering a 'one-stop shop' for all marine activities. The MMO's planning jurisdiction includes the waters off the coast of England and for the whole of the offshore area of Great Britain, beyond 12 nautical miles ${ }^{15}$. For Welsh territorial waters (generally within 12 nautical miles) the Welsh Assembly Government will be the presiding planning authority ${ }^{15}$.

Northern Ireland is expected to develop its own marine planning regime through its own legislative process though will agree final terms with the UK Government. The Scottish Government intend to pursue marine planning in Scottish territorial waters more autonomously through their own Scottish Marine Bill ${ }^{16}$.

Beyond this the MMO is also responsible for facilitating maritime information dissemination, facilitating 'access and use data and information to create maps, graphs, tables and reports...' relating to '...habitats, species types, distribution, bathymetry, geology and hydromorphology... along with information about marine uses and other socio-economic data ${ }^{15}$. The MMO will encourage interaction between data suppliers and data users, likely to include the existing UK Directory of Marine Observing Systems (UKDMOS) and the UK Marine Monitoring and Assessment Strategy (UKMMAS). Conservation is prioritised in the Bill, providing the legislative mechanisms for establishing Marine Conservation Zones $(\mathrm{MCZ})^{15}$. The statutory nature conservation agencies, Natural England, the Joint Nature Conservation Committee (JNCC) and the Countryside Council for Wales (CCW), are currently developing programmes to designate potential MCZ 
sites. These zones are expected to be established by the end of $2012^{15}$.

\section{Strategic Environmental Assessment}

The European Commission have also drafted a 'Strategic Environmental Assessment' Directive to ensure that the environmental consequences of certain plans or programmes are identified and addressed before beginning. The directive also makes the planning process more transparent by endorsing public consultation ${ }^{8}$. A Strategic Environmental Assessment (SEA) is designed to assist each project with their individual 'Environmental Impact Assessments', another European Directive.

So far the UK through DBERR has undertaken eight SEAs, the latest one being Offshore Oil and Gas Licensing and Wind Leasing. This does not cover marine energy technologies. However, an SEA for marine energy in the Severn Estuary has been included a barrage feasibility study, though this only includes tidal range options. Scotland, with their focus on marine energy commissioned Faber Maunsell and METOC Plc to undertake an SEA in 2004 under the guidance of the Marine Energy Group. The SEA covers wave and tidal stream devices, but does not include tidal range nor offshore wind. A further SEA for offshore wind in Scottish waters was announced in October $2008^{17}$.

The completion of the SEA has allowed the Crown Estate, who own the rights to the development of the seabed, to offer for lease the Pentland Firth and surrounding area, including the Orkney archipelago. This will allow for device deployment as early as 2010 .

The production of the SEA not only makes it easier for marine energy devices to deploy but also expounds a strong message from the Scottish Government to device developers and investors. Neither Wales, nor the UK have demonstrated this level of assurance to any emerging domestic marine energy industry.

\section{Wales}

The Welsh Assembly Government Renewable Energy Route Map for Wales ${ }^{18}$ includes an ambition to produce more electricity from renewables than Welsh consumers demand within 20 years. Consumption for 2006 was approximately $17.4 \mathrm{TWh}^{4}$, the Route Map anticipates up to $14 \mathrm{TWh}$ coming from the marine environment. Table IV breaks down these targets into individual marine resources.
Table IV. Welsh Assembly Government marine renewable energy targets for 2025 .

\begin{tabular}{|c|c|c|c|c|c|}
\hline & $\begin{array}{c}\text { Proposed } \\
\text { ROCs per } \\
\text { MWh }\end{array}$ & $\begin{array}{c}\text { Peak } \\
\text { electrical } \\
\text { power } \\
\text { MW(e) }\end{array}$ & $\begin{array}{l}\text { Electricity } \\
\text { load factor } \\
(\%)\end{array}$ & $\begin{array}{c}\text { Electrical } \\
\text { energy } \\
\text { generated } \\
\text { TWh(e)/yr }\end{array}$ & $\begin{array}{c}\text { Potential } \\
\text { carbon } \\
\text { savings } \\
\text { tons/year }\end{array}$ \\
\hline $\begin{array}{l}\text { Severn } \\
\text { barrage }\end{array}$ & $\mathrm{N} / \mathrm{A}$ & 8,500 & 25 & $\begin{array}{l}9 \text { (Wales' half } \\
\text { of total } \\
\text { generation) }\end{array}$ & $1,050,000$ \\
\hline $\begin{array}{c}\text { Other marine } \\
\text { including } \\
\text { wave, tidal } \\
\text { stream, } \\
\text { lagoons }\end{array}$ & 2 & $\begin{array}{c}1,000 \text { to } \\
2,000\end{array}$ & 30 & 2.5 to 5 & $\begin{array}{l}300,000- \\
600,000\end{array}$ \\
\hline Total & & $\begin{array}{l}\text { Up to } \\
10,500 \mathrm{MW}\end{array}$ & & Up to $14 \mathrm{TWh}$ & $\begin{array}{c}\text { Up to } \\
1,600,000 \mathrm{t} / \mathrm{yr}\end{array}$ \\
\hline
\end{tabular}

The Route Map commits to 'support opportunities for and encourage various marine feasibility studies and research into specific technologies' as well as to 'examine whether EU Convergence Funds could be used to...support the preparatory phases of constructing perhaps the world's first tidal-energy lagoon, ${ }^{18}$. Possibly the most significant announcement is the promise of a Wales Marine Energy Action Plan, looking to put Wales at the forefront of marine energy developments over the next 30 years $^{18}$.

Whilst Wales has great ambition for the future of marine energy, as iterated in the Renewable Energy Route Map for Wales, there appears to be few incentives for the industry to develop beyond early stage research. Scotland, partially due to location and resource, has made considerably more progress toward device deployment and commercialisation. The significant tangible differences are the completed SEA and the EMEC facility. To catch up the Welsh Assembly Government should initiate an SEA as early as possible. This will answer environmental questions as well as prove to the fledgling industry that Wales is committed to the technology. Infrastructural plans, such as electricity connectivity and transmission will also need to be addressed. Future policy will be informed by the publication of the Welsh Marine Renewable Energy Strategic Framework, at the end of RPS Group's contract in June $2010^{19}$.

\section{Conclusions}

For Wales and the UK as a whole, the prospect of a new marine renewable energy industry has a multitude of advantages, beyond meeting renewable energy or carbon reduction targets. Domestically-sourced energy will help alleviate energy security concerns. The creation of the industry will give employment opportunities as well as the potential to export energy conversion devices and expertise. Lessons can be drawn from the development of the wind industry, where the countries with the greatest domestic support have prevailed to export their devices internationally, where others, including the UK have forgone their own industry in favour of importing. Political will is essential for barriers to be removed, investment to be encouraged and devices to be deployed, if the UK is to establish itself as the marine energy market leader. 


\section{Acknowledgements}

This research was funded by a European Regional Development Fund grant through the Welsh Assembly Government and the Knowledge Exploitation Fund.

\section{References}

1. UK Parliament Publications, (2001), Select Committee on Science and Technology, Seventh Report: Wave and Tidal Energy, Available online:

http://www.publications.parliament.uk/pa/cm200001/cms elect/cmsctech/291/29105.htm\#a14 [Accessed 24 April 2008]

2. AEA Energy and Environment, (2007), Tidal Energy Case Studies: Review of Severn UK Tidal Energy Case Studies, SDC

3. Black \& Veatch, (2005), Tidal Stream - Phase II UK Tidal Stream Energy Resource Assessment, Carbon Trust

4. BERR, (2008), Digest of United Kingdom Energy Statistics 2008, The Stationary Office, London

5. Carbon Trust, (2006) Future Marine Energy: Results of the Marine Energy Challenge: Cost competitiveness and growth of wave and tidal stream energy, Carbon Trust

6. Europa, (2008), Boosting growth and jobs by meeting our climate change commitments, Available online: http://europa.eu/rapid/pressReleasesAction.do?reference= IP/08/80\& format=HTML\&aged $=0$ \&language $=E N \&$ guiL anguage $=$ en $[$ Accessed on 07 January 2009.

7. Commission of the European Communities, (2007), An Energy Policy for Europe, COM(2007) 1 final, Available online:

http://register.consilium.europa.eu/pdf/en/07/st05/st0528

2.en07.pdf [Accessed on 07 January 2009]

8. Europa, (2008), Strategic Environmental Assessment: legal context, Available online:

http://ec.europa.eu/environment/eia/sea-legalcontext.htm [Accessed on 24 June 2008]

9. BERR, (2008), UK Renewable Energy Strategy Consultation, HMSO, London
10. ETI, (13/01/2009), News - Energy Technologies Institute Unveils First Projects to Benefit From $£ 1.1$ Billion Initiative, Available online: http://www.energytechnologies.co.uk/home/news/09-01-

11. Renewables Advisory Board, (2008), Marine Renewables: Current Status and implications for $R \& D$ funding and the Marine Renewables Deployment Fund, $\mathrm{RAB}$

12. SWRDA, South West of England Regional Development Agency, South West England Wave Hub Project, Available online: www.wavehub.co.uk [Accessed on 11 July 2008]

13. SWRDA, (2008), South West of England Regional Development Agency, RDA Sets New Timetable for Wave Hub, Available online: http://www.southwestrda.org.uk/news/release.asp?Releas eID=2426 [Accessed on 11 July 2008]

14. DTI, (2007), A White Paper on Energy: Meeting the Energy Challenge, The Stationary Office, London

15. DEFRA, (2008), Draft Marine Bill: Policy Paper, The Stationary Office, London

16. The Scottish Government, (2009), Marine Bill, Available online:

http://www.scotland.gov.uk/Topics/Environment/Water/1 6440/marine-bill-consultation Accessed on 12/02/2009]

17. The Scottish Government, (2008), Potential of Offshore Wind Energy, Available online:

http://www.scotland.gov.uk/News/Releases/2008/10/291 12030 [Accessed on 11/02/2009]

18. Welsh Assembly Government, (2008), Renewable Energy Route Map for Wales, WAG

19. Welsh Assembly Government, (2007), Contract Award: Marine Renewable Energy Strategy for Wales, Available online:

http://wales.gov.uk/topics/improvingservices/bettervfm/s martpurchasing/wob/contracts/1392006/;jsessionid=XJ6J JnzWJj3VFfZ0knhY7VrQ0L0NZnxCKb3wf2WcyfJzJ2t n9Z2c!-305112990?lang=en 